\title{
THE INFLUENCE OF FACTORS ON THE MODIFICATION OF THE FINAL OPINION OF THE AUDITOR IN THE OFFICIAL REPORT: FROM STANDARDS TO PRACTICE
}

\author{
Dmytrenko I.N. \\ Doctor of Economics, Associate Professor, Professor of the National Center for Accounting and \\ Auditing of the National Academy of Statistics, Accounting and Auditing, Ukraine \\ irynadmytrenko1308@gmail.com
}

\begin{abstract}
The subject of this publication is the classification and systematization of factors that influence the modification of the auditor's opinion in the official report on the accuracy of the financial statements of client companies. A cluster of influencing factors was substantiated and proposed, based on the possible presence of material misstatements, events of significant uncertainty, and full disclosures in the notes to the financial statements. On the basis of a comparative analysis of statistical data on the results of mandatory and initiative audit, the main trends in the ratio of various types of auditors' opinions and the degree of their modification, formed in the main segment of the audit services market in Ukraine, are identified. The logical chain of transforming the auditor's professional judgment into a final opinion in a general format, as well as taking into account the effect of significant uncertainty events, is substantiated and presented. As a tool for the practical implementation of the requirements of the International Auditing Standards, Matrices of dependence of the influential groups of factors and the degree of modification of the auditor's opinion under specific circumstances and results of the assignment are proposed.

The purpose of the study was to identify and systematize the factors that influence the modification of the final opinion on the reliability of the financial statements of client enterprises in the official report of the auditor; in the development of tools for the practical implementation of the requirements of international professional standards to justify the degree of modification of opinion, providing sufficient confidence to interested users, minimizing their information risks.

Sources and research methods: the information base of the research was the International Standards for Quality Control, Audit, Review, Other Provision of Confidence and Related Services (2016-2017) of the Council on International Standards on Auditing and Providing Confidence of the International Federation of Accountants; official statistics on the market of audit services in Ukraine (2014-2017); scientific publications; personal observations of the author.

The study used methods of analysis and synthesis; systematic approach and systematization; dialectical, logical, economic and statistical methods.

Results and practical significance: the obtained results allow us to conclude that in order to ensure the proper quality of performance of tasks for auditing the financial statements, auditing entities must, with due care and professional skepticism, approach the substantiation of their opinion, especially if it is modified. The proposed logical chain of formation of professional judgment and independent opinion of the auditor focuses on the general and specific factors influencing the choice of its type. The pragmatic value of the research is the algorithm for determining the effect of compliance with the assumption of the continuity of client enterprises on the choice of the type of auditor's opinion with regard to its possible modification. Matrices of influence of influential groups of factors and the degree of modification of the auditor's opinion (a opinion with caution, a negative opinion, a refusal to express an opinion) are tools for effective navigation in order to
\end{abstract}


implement the requirements of the International Standards on Auditing.

Keywords: professional judgment, opinion of an independent auditor, provision of confidence, modification of opinion, material distortions, substantial uncertainty, continuity of activity.

\section{INTRODUCTION}

The problem of forming the structure and content of the official report of an independent auditor in an adequate format for interested users constantly accompanies the theory and practice of auditing throughout the history of the establishment and development of the audit institution. This is typical both for the international auditing public and for the professional auditing public in Ukraine.

The increased interest in solving this problem is due to the dynamics and vector of information requests from stakeholders in response to a significant increase in the level of information risks, especially among public interest enterprises. The desire to strengthen public confidence in the profession of an auditor and to ensure public recognition of its need draws the Council on International Standards on Auditing and Providing Confidence of the International Federation of Accountants to constantly review and strengthen the requirements of international professional standards for the quality of the report of an independent auditor [13]. This concerns the standardization of an integrated approach to the consideration of all factors influencing the justification of the auditor's opinion in the final report, taking into account its possible modification. In the International Standards for Quality Control, Audit, Review, Other Provision of Confidence and Related Services (ISA) (publications 2015 and 2016-2017). The main focus is on expressing opinions not only about the reliability of the financial statements of client companies, but more about the ability of companies to ensure the continuity of their activities in the foreseeable future.

The evolution of the requirements for the report format of an independent auditor can be traced in the fundamental works of the classics of audit [1], [4], [11], [17] and their followers, the main ones being works [2], [3], [5], [6], [7], [8], [9], [10], [16], [18], [19], [20], [21], [23].

For the auditing public of Ukraine, a landmark event affecting the additional strengthening of the quality assurance requirements for mandatory audit of financial statements of enterprises of public interest was the entry into force on October 1, 2018 of a new version of the Law of Ukraine "On Auditing Financial Reporting and Auditing Activity" № 2258-VIII 21.12.2017 [22]. And this is despite the fact that in Ukraine the International Standards on Auditing have been used as national standards since 2004.

With the adoption of the new formalized structure of the audit report, the question of the validity of the use of professional judgment by auditors, on the basis of which the decision on the choice of the type of independent opinion in the final report is made, remains open.

Therefore, it is important to identify and systematize the factors that influence the modification of the final opinion in the official report of the auditor, as well as to offer tools for the practical implementation of the requirements of international professional standards to justify the extent of this modification of opinion. That was the purpose of our research.

\section{SOURCES AND METHODS}

The study used methods of analysis and synthesis; systematic approach and systematization; dialectical, logical, economic and statistical methods.

Using the methods of analysis and synthesis allowed to direct research to determine the dependence of general factors on the formation of professional judgment of the auditor and the final opinion on the objectives of evaluation of individual objects within the overall objective of the audit of financial statements of client companies.

Thus, the purpose of an audit of the business process system is to identify the business model's ability to be used by the client company to create the value and degree of risk of distortion of information at the level of business processes, which in turn may cause distortion of the accounting information and corporate reporting of the group of companies and its components

The accounting and corporate reporting system is an identification of the risk of material misstatement of corporate reporting information at the level of statements on account balances, transaction and event classes, disclosure and presentation of corporate reporting information, as well as the risk of material misstatement of specific for consolidated reporting entities.

Regarding the system of internal control, it is the identification of the level of reliability and the corresponding risk of inefficiency in the functioning of this system, which affects the professional judgment of the auditor 
regarding the optimal selection of procedures for obtaining evidence (by nature, time and volume).

With regard to the business risk management system, the identification of the ability of this system to influence the manageability of business risks and create conditions for accepting such a level of risk, which corresponds to the company's risk appetite, the presence of uncovered (residual) risk, its impact on professional judgment and the choice of the type of independent opinion of the auditor taking into account the degree of adherence to the assumption of the continuity of the client company.

Regarding the corporate governance system, this is the identification of the ability of this system to prevent and minimize corporate conflicts of interest, as well as the risk of discretionary behavior of management and violation of owner rights, which affects the professional judgment of the existence of a situation of significant uncertainty and ensuring that the client company adheres to the assumption of continuity of activities, sustainability of further development.

Consider the factors influencing the results of the audit of these system objects for the justification of the auditor's professional judgment and certain consequences of its use. Consequently, the logic of the general approach to the formation of professional judgment and independent opinion of the auditor is shown in Fig. 1

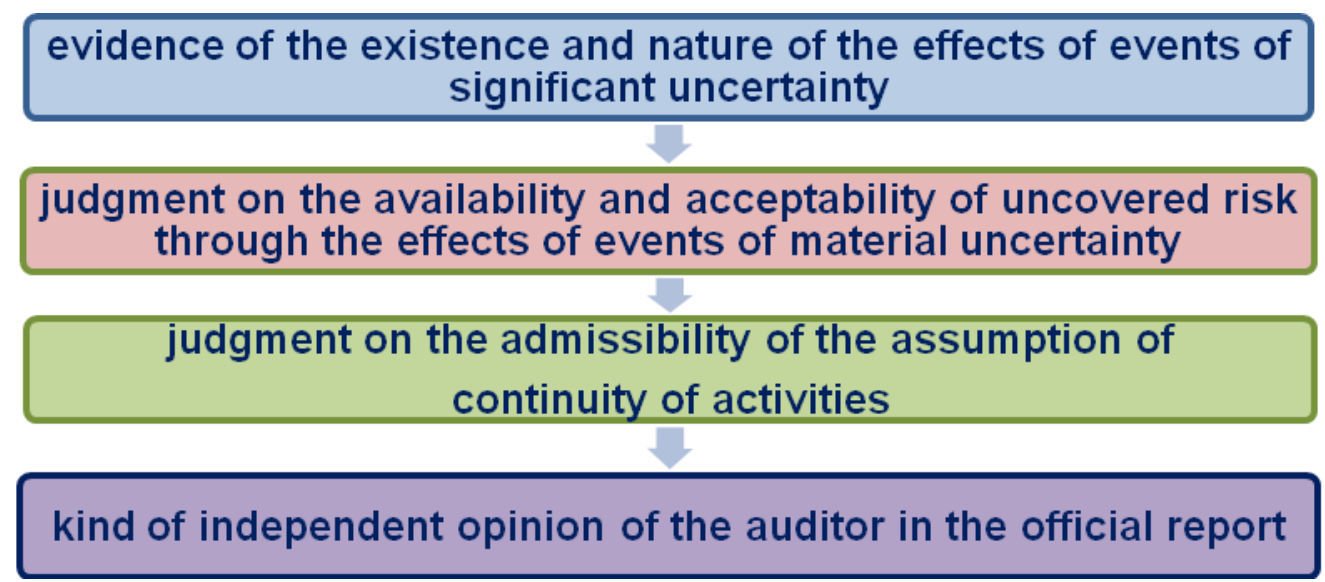

Fig. 1. Logical chain of formation of professional judgment and independent opinion of the auditor
on the influence of events of significant uncertainty Source: compiled by the author

System approach, logical analysis and systematization have contributed to the definition of a number of international auditing standards that, if they meet their requirements, are designed to provide the appropriate level of reasonableness of professional judgment and auditor's opinion in the official report.

When justifying the choice of the type of independent opinion, reference should be made to the requirements of professional standards, in particular, ISA 700 "Formulating Thoughts and Compiling Financial Reporting Report", ISA 701 "Notification of Information on Key Auditing Issues in an Independent Auditor's Report", ISA 705 "Modification of Thought in Independent Auditor's Report", ISA 706 "Explanatory paragraphs and paragraphs on other issues in the report of an independent auditor", ISA 710 "Explanatory Information Relevant Indicators and Comparative Financial Statements", ISA 720 "Auditor's Responsibility on other information", ISA 320 "Significance in planning and conducting an audit", ISA 450 "Estimation of distortions detected during the audit", ISA 560 "Further events", ISA 570 "Continuity of activity", ISA 580 "Written assurances", ISA 260 "Communication of information to those who have the highest authority" [13].

Consequently, the auditor chooses the opinion expressed by him: unmodified opinion, or modified versions opinion with caution, negative opinion, refusal to express an opinion, taking into account the influence of certain factors.

The general factors that influence the selection of certain types of opinions by the auditor and individual language designs for their formulation in the official report are given in Table 1.

The procedure for modifying the opinion and its expression in the report of an independent auditor is regulated by ISA 705 "Modifications of opinion in the report of an independent auditor" [13].

The auditor expresses a modified opinion in the audit report if it:

- Comes to the conclusion that, on the basis of the audit evidence obtained, the financial statements as a whole contain material misstatements; or 
- It is not possible to obtain sufficient and appropriate audit evidence in order to conclude that the financial statements as a whole are free from material misstatement.

The opinion with caution is expressed by the auditor if he:

- Having obtained sufficient and relevant evidence, concludes that distortion taken alone or in aggregate is material, but not comprehensive for financial reporting; or

- It is not possible to obtain sufficient and appropriate audit evidence to substantiate an opinion, however, it comes to the conclusion that the possible impact on the financial statements of uncorrected misstatements, if any, may be significant, but not all-encompassing.

The opinion with caution should contain the phrase "with the exception of" the effects of the events to which the reservation relates.

Table 1. General factors influencing the choice of the type of independent auditor's opinion and its formulation in the official report

\begin{tabular}{|c|c|c|c|c|}
\hline 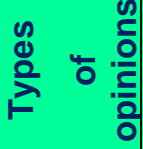 & $\begin{array}{l}\text { Unmodified } \\
\text { opinion }\end{array}$ & $\begin{array}{l}\text { Opinion with } \\
\text { caution }\end{array}$ & $\begin{array}{l}\text { Negative } \\
\text { opinion }\end{array}$ & $\begin{array}{l}\text { Refusal to } \\
\text { express an } \\
\text { opinion }\end{array}$ \\
\hline oñ & $\begin{array}{l}\text { - All necessary and } \\
\text { sufficient information for } \\
\text { audit purposes is provided; } \\
\text { - the data are adequate in } \\
\text { terms of reliability, } \\
\text { objectivity, completeness of } \\
\text { the content of information; } \\
\text { - the financial } \\
\text { documentation complies } \\
\text { with the legislation adopted } \\
\text { by the company's } \\
\text { accounting policies; } \\
\text { - the financial statements } \\
\text { contain reliable and } \\
\text { objective accounting } \\
\text { records in all material } \\
\text { respects; } \\
\text { - financial statements in all } \\
\text { material respects have } \\
\text { been drawn up in } \\
\text { accordance with the } \\
\text { applicable conceptual } \\
\text { framework; } \\
\text { - accounting and internal- } \\
\text { corporate control systems } \\
\text { are adequate to the } \\
\text { requirements of the } \\
\text { standards }\end{array}$ & $\begin{array}{l}\text { - Restrictions on } \\
\text { obtaining evidence } \\
\text { that do not have a } \\
\text { comprehensive } \\
\text { impact on the } \\
\text { rationale of thought; } \\
\text { - Identified } \\
\text { deviations require } \\
\text { correction, are } \\
\text { substantial but not } \\
\text { comprehensive }\end{array}$ & $\begin{array}{l}\text { - Unsatisfactory } \\
\text { accounting status; } \\
\text { - incomplete } \\
\text { accounting of } \\
\text { transactions, } \\
\text { which is } \\
\text { substantial and } \\
\text { inclusive; } \\
\text { - significant } \\
\text { discrepancies in } \\
\text { the amounts of } \\
\text { financial } \\
\text { statements with } \\
\text { the accounting } \\
\text { records; } \\
\text { - significant } \\
\text { violations of the } \\
\text { accounting } \\
\text { methodology; } \\
\text { - the execution } \\
\text { and execution of } \\
\text { operations is not } \\
\text { in accordance } \\
\text { with the current } \\
\text { legislation }\end{array}$ & $\begin{array}{l}\text { - Violation of the } \\
\text { auditor's } \\
\text { independence; } \\
\text { - lack of } \\
\text { sufficient } \\
\text { evidence in the } \\
\text { presence of } \\
\text { simultaneously } \\
\text { significant and } \\
\text { comprehensive } \\
\text { effects of } \\
\text { expected } \\
\text { distortions }\end{array}$ \\
\hline
\end{tabular}




\begin{tabular}{|c|c|c|c|c|}
\hline 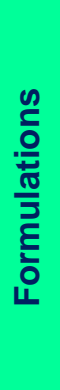 & $\begin{array}{l}\text { • "meets the requirements" } \\
\text { • "properly" } \\
\text { • "gives a credible and } \\
\text { objective presentation" } \\
\text { - "reliably reflects" }\end{array}$ & $\begin{array}{l}\text { - "basically meets } \\
\text { the requirements" } \\
\text { - "generally reflects } \\
\text { credibly and } \\
\text { objectively" } \\
\text { - "except for } \\
\text { specified } \\
\text { restrictions" }\end{array}$ & $\begin{array}{l}\text { - "does not meet } \\
\text { the requirements" } \\
\text { - "does not give a } \\
\text { true and fair view" } \\
\text { - "distorts the } \\
\text { actual state of } \\
\text { affairs" } \\
\text { - "contradict" }\end{array}$ & $\begin{array}{l}\text { - "we were } \\
\text { invited to } \\
\text { conduct an } \\
\text { audit" } \\
\text { - "it has not } \\
\text { been possible to } \\
\text { gather sufficient } \\
\text { and relevant } \\
\text { audit evidence" }\end{array}$ \\
\hline
\end{tabular}

Source: compiled by the author on the basis of [13]

Overarching is the effect of distortions on the financial statements, which, based on the auditor's professional judgment:

- is not limited to specific elements, accounts or items of financial statements;

- is limited, but it covers or may cover a significant part of the financial statements;

- is essential for users to understand financial statements when it comes to disclosing information.

A negative opinion is expressed by the auditor if he, having obtained sufficient and relevant audit evidence, comes to the conclusion that the distortions, taken separately or in aggregate, are both essential and allencompassing for the financial statements.

Refusal to express an opinion is applied by the auditor if he is unable to obtain sufficient and relevant audit evidence to substantiate the opinion and concludes that the possible impact on the financial statements of undetected misstatements, if any, can be both essential and comprehensive.

If the auditor expresses an opinion other than unmodified, he should clearly describe all the significant reasons for this in the paragraph of the report "Grounds for expressing caution (or a negative opinion, or refusing to express an opinion)" and, if possible, give a quantitative description of this effect on financial statements.

This paragraph should be posted in the report after expressing an opinion or refusing to express an opinion, and may include references to more detailed information in the notes to the financial statements.

If the auditor expresses a modified opinion, he should use the specific heading "Opinion with caution", "Negative opinion" or "Refusal to express an opinion" depending on the circumstances for the paragraph "Opinion".

Inclusion in the audit report of additional explanatory information is regulated by ISA 706 "Explanatory paragraphs and paragraphs on other issues in the report of an independent auditor" [13].

The explanatory paragraph is included by the auditor in the report if it concerns a question that is properly presented or disclosed in the financial statements, and according to the auditor's judgment, is so important that it is fundamental for users to understand the financial statements.

If the auditor includes an explanatory paragraph in the audit report, he:

- in this paragraph clearly indicates the issue that is covered, and where exactly in the financial statements you can find information that fully discloses it;

- indicates that the audit opinion is not modified due to the lit issue.

Usually, the inclusion of an explanatory paragraph in an audit report occurs when the auditor identifies significant uncertainties that may cast doubt on the relevance of the assumption about the continuity of the client company, affect the financial statements, and minimizing or eliminating its impact depends on future events.

Uncertainty is a factor whose consequences depend on future events that are not under the direct control of a business entity, but which may have an impact on financial statements. For example, circumstances that give rise to the need to include an explanatory paragraph in an audit report may include: uncertainty about the future results of an unforeseen legal process or the actions of regulatory authorities; a big catastrophe that caused significant damage and continues to significantly affect the financial situation of a business entity.

On the basis of a comparative analysis of statistical data on the results of mandatory and initiative audit, the 
main trends in the ratio of various types of auditors' opinions and the degree of their modification, formed in the main segment of the audit services market in Ukraine for 2014-2017, are revealed Table 2.

According to Table 2 data, for the period 2014-2107 there is a tendency to reduce the number of accomplished tasks of assurance in the main segment of the Ukrainian audit services market. Accordingly, according to the mandatory audit, the number of tasks decreased by $20,3 \%$, and on the initiative - by $0,9 \%$. This tendency is also confirmed by a decrease in the ratio of the total number of tasks from compulsory and initiatory audit (from 3,5 to 2,7 ).

However, the proportion of reports with negative opinion and the refusal to express opinions on both mandatory and on the initiative audit has a relatively well-established state. For the period 2014-2107, according to the statutory audit, it is about $2 \%$, and on the initiative audit - about $3 \%$, which indicates a certain degree of circumstances or the absence of additional circumstances from the client companies that would force the auditors to substantially modify the opinion or to refuse her statement.

Table 2. A comparative analysis of trends in types of opinion in the reports of independent auditors of Ukraine for 2014-2017

\begin{tabular}{|c|c|c|c|c|c|c|c|c|}
\hline \multirow{2}{*}{$\begin{array}{l}\text { Types of opinions in } \\
\text { the auditors' reports }\end{array}$} & \multicolumn{2}{|c|}{2014} & \multicolumn{2}{|c|}{2015} & \multicolumn{2}{|c|}{2016} & \multicolumn{2}{|c|}{2017} \\
\hline & $\begin{array}{l}\text { Number } \\
\text { of tasks }\end{array}$ & $\%$ & $\begin{array}{l}\text { Number } \\
\text { of tasks }\end{array}$ & $\%$ & $\begin{array}{l}\text { Number } \\
\text { of tasks }\end{array}$ & $\%$ & $\begin{array}{l}\text { Number } \\
\text { of tasks }\end{array}$ & $\%$ \\
\hline \multicolumn{9}{|c|}{ On the task of compulsory audit of financial statements } \\
\hline Unmodified opinion & 1787 & 23,9 & 1556 & 21,6 & 1308 & 20,8 & 1391 & 23,4 \\
\hline Opinion with caution & 5549 & 74,4 & 5543 & 77,0 & 4850 & 77,2 & 4428 & 74,5 \\
\hline Negative opinion & 92 & 1,2 & 62 & 0,9 & 100 & 1,6 & 90 & 1,5 \\
\hline $\begin{array}{l}\text { Refusal to express an } \\
\text { opinion }\end{array}$ & 34 & 0,5 & 35 & 0,5 & 28 & 0,4 & 38 & 0,6 \\
\hline Total compulsory audit & 7462 & 100,0 & 7196 & 100,0 & 6286 & 100,0 & 5947 & 100,0 \\
\hline \multicolumn{9}{|c|}{ On the tasks of the initiative audit of financial statements } \\
\hline Unmodified opinion & 979 & 45,4 & 918 & 47,3 & 896 & 46,3 & 1040 & 48,6 \\
\hline Opinion with caution & 1122 & 52,0 & 969 & 50,0 & 989 & 51,1 & 1044 & 48,8 \\
\hline Negative opinion & 40 & 1,9 & 36 & 1,9 & 27 & 1,4 & 36 & 1,8 \\
\hline $\begin{array}{l}\text { Refusal to express an } \\
\text { opinion }\end{array}$ & 16 & 0,7 & 16 & 0,8 & 23 & 1,2 & 18 & 0,8 \\
\hline Total initiative audit & 2157 & 100,0 & 1939 & 100,0 & 1935 & 100,0 & 2138 & 100,0 \\
\hline $\begin{array}{l}\text { Ratio of total number } \\
\text { of tasks }\end{array}$ & 3,5 & - & 3,7 & - & 3,2 & - & 2,8 & - \\
\hline
\end{tabular}

Source: compiled by the author on the basis of [12]

The largest share is reported in the reports with the warning that on the tasks from the mandatory audit for the period $2014-2107$ an average of $75,6 \%$, and on the basis of the task of the initiative audit - 50,5\%. Regarding the unmodified opinion, the established trend in these areas was determined during the analyzed period: according to the task of compulsory audit - the average indicator is $22,4 \%$, according to the task of the initiative audit $-46,9 \%$. A lower indicator of the proportion of mandatory audit tasks (2 times) compared 
with the initiative audit confirms the existence of more stringent requirements for justification of the auditor's opinion additionally by the regulatory authorities of Ukraine (in particular, the National Commission on Securities and Stock Market, National Commission for the Regulation of the Financial Services Market, National Bank of Ukraine). This tendency will continue to grow, taking into account the need for additional requirements for the formation of an audit opinion in accordance with the Law of Ukraine "On Audit of Financial Reporting and Audit Activity " [22].

The system approach and systematization facilitated the identification and generalization of a cluster of specific factors based on the possible existence of significant distortions, the effects of events of material uncertainty, and the completeness of disclosure in the notes to the financial statements.

\section{RESULTS}

Therefore, we will consider in more detail the most significant of the specific factors affecting the professional judgment and the independent opinion of the auditor, which are grouped by us as follows:

1) the degree of adherence to the assumption of continuity of the company-client - Table 3;

2) the degree of materiality of the detected and expected distortions of financial reporting and the degree of audit risk - Table 4;

3) the degree of reliability of the initial and comparative indicators of financial reporting - Table 5;

4) the state of use of the work of experts (in the case of such events of significant uncertainty that go beyond the competence of the auditor) - Table 6;

5) availability and condition of operations of the client company with affiliated parties - Table 7.

Table 3. Factors influencing the assumption of the continuity of activities to select the type of opinion of the auditor in the official report

\begin{tabular}{|c|c|c|c|c|c|}
\hline \multirow{3}{*}{ Factors of influence } & \multicolumn{5}{|c|}{ Types of Thoughts in the Independent Auditor's Report } \\
\hline & \multicolumn{2}{|c|}{ Unmodified } & \multicolumn{3}{|c|}{ Modified } \\
\hline & $\begin{array}{l}\text { without } \\
\text { explanatory } \\
\text { paragraph }\end{array}$ & $\begin{array}{l}\text { with an } \\
\text { explanatory } \\
\text { paragraph }\end{array}$ & $\begin{array}{c}\text { with a } \\
\text { warning }\end{array}$ & negative & refusal \\
\hline $\begin{array}{l}\text { 1. Absence of doubt as to compliance } \\
\text { with the assumption of continuity of } \\
\text { activities }\end{array}$ & + & & & & \\
\hline $\begin{array}{l}\text { 2. Doubts regarding adherence to the } \\
\text { assumption of continuity of activities } \\
\text { under the conditions of full disclosure in } \\
\text { the notes to the financial statements }\end{array}$ & & + & & & \\
\hline $\begin{array}{l}\text { 3. Non-disclosure, incomplete disclosure } \\
\text { of events of material uncertainty in notes } \\
\text { to financial statements }\end{array}$ & & & + & + & \\
\hline $\begin{array}{l}\text { 4. Insufficiency of financial reporting as a } \\
\text { result of non-compliance with the } \\
\text { assumption of continuity of activities }\end{array}$ & & & & + & \\
\hline $\begin{array}{l}\text { 5.Significant and comprehensive } \\
\text { uncertainty about the possibility of } \\
\text { adhering to the assumption of continuity } \\
\text { of activities }\end{array}$ & & & & & + \\
\hline
\end{tabular}


Source: compiled by the author on the basis of [13]

The algorithm for determining the influence of the degree of adherence to the assumption of the continuity of activity of the company-client on the choice of independent auditor's opinion is given in Figure 2.

It should be noted that the auditor's doubts regarding compliance by the client company with the assumption of continuity of activities can cause situations of significant uncertainty. Such situations are manifested in the assessment of the quality of the business processes system (regarding the ability of the company's business model to create value); business risk management systems (regarding the availability of residual risk and the ability of this system to direct its consequences in the foreseeable future); corporate governance systems (regarding the ability of representative bodies of owners and executive bodies of the company to prevent and minimize corporate conflicts of interest).

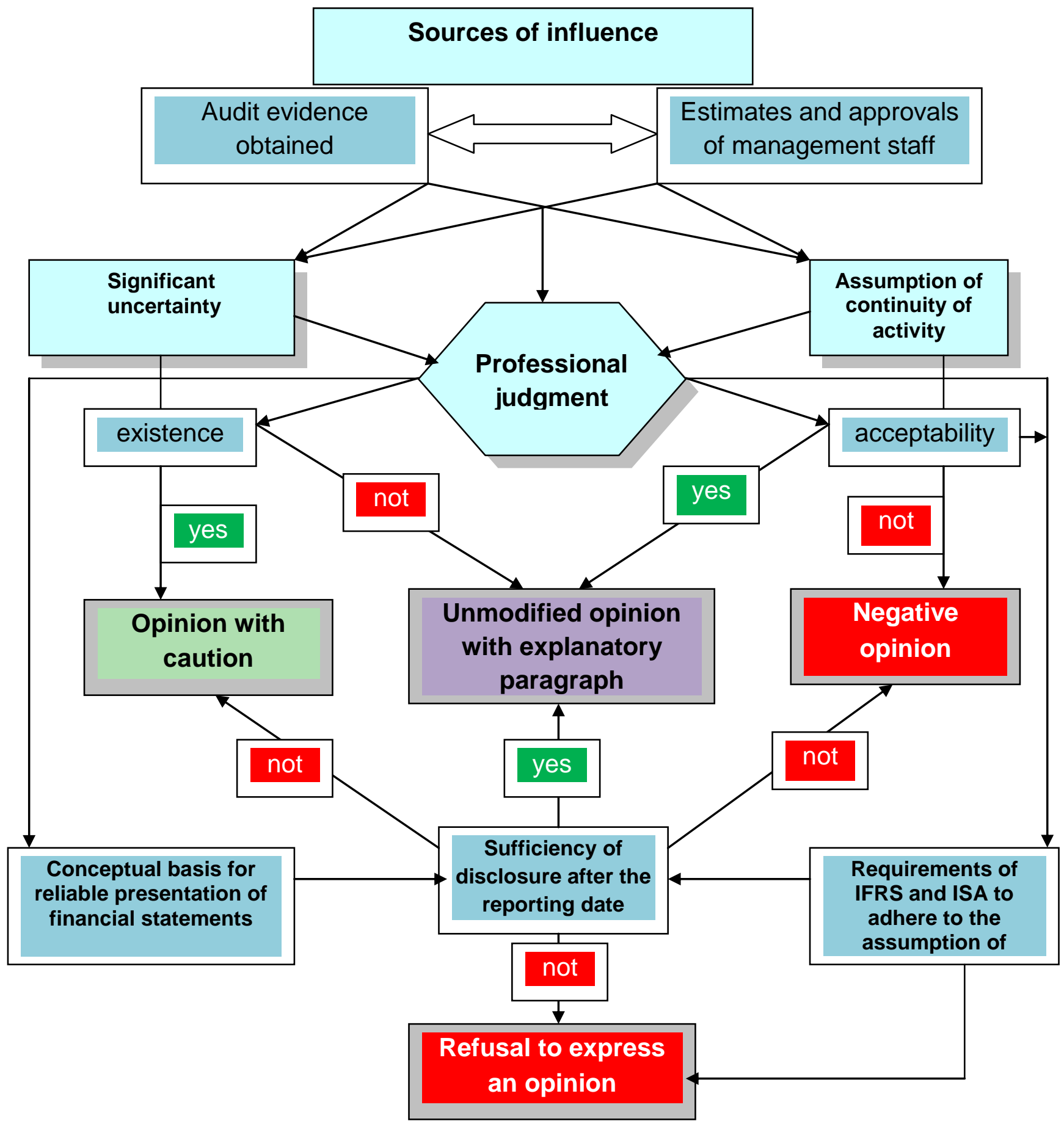


Fig. 2. The algorithm for determining the impact of the assumption of the continuity of the activities of client companies on the type of auditor's independent opinion

\section{Source: compiled by the author}

In Table 4 systematized the degree of influence of the materiality of the detected and expected distortions of financial reporting on the choice of the type of independent opinion and the way of its formulation in the audit report. Consequently, in the event of significant and unbalanced distortions in financial reporting, there is no reason to formulate an opinion with an explanatory paragraph and leave it still unmodified. In case of impossibility to reduce the risk of non-detection of distortions of financial reporting by expanding the information field and the use of additional audit procedures, there are grounds for refusing to express an opinion.

Table 4. Factors influencing significant distortions of financial statements to select the type of auditor's independent opinion in the report

\begin{tabular}{|l|l|l|l|l|l|}
\hline \multicolumn{2}{|c|}{ Factors of influence } & \multicolumn{2}{c|}{ Types of Thoughts in the Independent Auditor's Report } \\
\cline { 2 - 6 } & $\begin{array}{c}\text { Unmodified } \\
\text { without } \\
\text { explanatory } \\
\text { paragraph }\end{array}$ & $\begin{array}{c}\text { with an } \\
\text { explanatory } \\
\text { paragraph }\end{array}$ & $\begin{array}{c}\text { with a } \\
\text { warning }\end{array}$ & negative & refusal \\
\hline $\begin{array}{l}\text { 1. Detected and expected distortions in } \\
\text { the financial statements amount to a } \\
\text { value that is significantly less than the } \\
\text { established level of materiality and } \\
\text { insignificant qualitative discrepancies } \\
\text { regarding the applied accounting and } \\
\text { reporting procedures and the normative } \\
\text { basis (conceptual basis) }\end{array}$ & + & & & \\
\hline $\begin{array}{l}\text { 2. Dissatisfaction of the management of } \\
\text { the client company to make adjustments } \\
\text { to eliminate detected and expected } \\
\text { significant distortions of financial } \\
\text { statements (depending on the degree of } \\
\text { materiality) }\end{array}$ & & & & \\
\hline $\begin{array}{l}3 . \text { The inability to reduce the risk of not } \\
\text { detecting significant distortions to an } \\
\text { acceptable level }\end{array}$ & & & & \\
\hline $\begin{array}{l}\text { 4. Detected and expected distortions in } \\
\text { the financial statements amount to a } \\
\text { value that is significantly higher than the } \\
\text { established level of materiality }\end{array}$ & & & & \\
\hline $\begin{array}{l}5 . \text { Significant nature of the qualitative } \\
\text { differences between the company-client } \\
\text { and the regulatory procedure for } \\
\text { accounting and preparation of financial } \\
\text { statements }\end{array}$ & & & & \\
\hline
\end{tabular}

Source: compiled by the author on the basis of [13], [14], [15]

The influence of the factor of reliability of the initial and comparative indicators of financial reporting on professional judgment and the corresponding choice of the type of professional opinion is summarized in Table 5. So, in this case, the grounds for formulating an unmodified thought that would contain an explanatory paragraph also does not arise. The auditor may refuse to express an opinion when it is not possible to obtain adequate and sufficient evidence.

Table 5. Factors influencing the validity of the initial and comparative reporting indicators for choosing the type of auditor's independent opinion in the report

\begin{tabular}{|c|c|c|c|c|c|}
\hline \multirow[b]{3}{*}{ Factors of influence } & \multicolumn{5}{|c|}{ Types of Thoughts in the Independent Auditor's Report } \\
\hline & \multicolumn{2}{|c|}{ Unmodified } & \multicolumn{3}{|c|}{ Modified } \\
\hline & $\begin{array}{l}\text { without } \\
\text { explanatory } \\
\text { paragraph }\end{array}$ & $\begin{array}{l}\text { with an } \\
\text { explanatory } \\
\text { paraqraph }\end{array}$ & $\begin{array}{c}\text { with a } \\
\text { warning }\end{array}$ & negative & refusal \\
\hline $\begin{array}{l}\text { 1. Initial and comparative financial } \\
\text { statements do not contain material } \\
\text { misstatements }\end{array}$ & 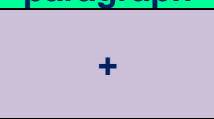 & & & & \\
\hline
\end{tabular}




\begin{tabular}{|l|l|l|l|l|l|}
\hline $\begin{array}{l}\text { 2. Separate initial and comparative } \\
\text { financial statements include distortions } \\
\text { that significantly affect the reliability of } \\
\text { financial statements (depending on the } \\
\text { degree of materiality of the distortion) }\end{array}$ & & & + & + & \\
\hline $\begin{array}{l}\text { 3. Initial and comparative financial } \\
\text { statements are unreliable }\end{array}$ & & & & + & \\
\hline $\begin{array}{l}4 . \text { Inability to obtain sufficient audit } \\
\text { evidence to verify the authenticity of the } \\
\text { initial and comparative financial } \\
\text { statements }\end{array}$ & & & & \\
\hline
\end{tabular}

Source: compiled by the author on the basis of [13], [14], [15]

As for the use of the work of experts, the influence of this factor is detailed in Table. 6.

Table 6. Factors influencing the results from involving experts in choosing the kind of auditor's independent opinion in the report

\section{Factors of influence}

1. Refusal of the client company to use the work of an expert (depending on the materiality of the controversial issue and the consequences of the risk of its failure)

2. Significant uncertainty of the expert regarding the assessment of the circumstances under study

3. Unresolved contradictions between the client company and the expert (depending on the materiality of the controversial issue)

4. Unresolved contradictions between the audit firm and the expert (depending on the substantiality of the controversial issue)

5. Inability to get an expert's conclusion

Source: compiled by the author on the basis of [13]

\begin{tabular}{|c|c|c|c|c|}
\hline \multicolumn{5}{|c|}{ Types of Thoughts in the Independent Auditor's Report } \\
\hline \multirow{2}{*}{$\begin{array}{c}\text { Unme } \\
\text { without } \\
\text { explanatory } \\
\text { paragraph }\end{array}$} & dified & & Modified & \\
\hline & $\begin{array}{l}\text { with an } \\
\text { explanatory } \\
\text { paragraph }\end{array}$ & $\begin{array}{c}\text { with a } \\
\text { warning }\end{array}$ & negative & refusal \\
\hline & & + & + & + \\
\hline & & & & + \\
\hline & & + & + & \\
\hline & & + & + & \\
\hline & & & + & + \\
\hline
\end{tabular}

From the data tab 6 it follows that, if necessary, the auditor's involvement with the expert on the resolution of controversial issues, the unmodified opinion can not be expressed. The level of modification of independent thought depends on the nature of the controversial issues and the degree of their resolution as a result of the involvement of an expert.

The presence and certain state of affairs of a client company with affiliated parties also causes the circumstances of the task to have an impact on the professional judgment and, subsequently, in the opinion of the auditor. The factors of such influence are summarized in Table 7.

Table 7. Factors influencing the transactions with affiliated parties to select the type of auditor's independent opinion in the report

\begin{tabular}{|c|c|c|c|c|c|}
\hline \multirow[b]{3}{*}{ Factors of influence } & \multicolumn{5}{|c|}{ Types of Thoughts in the Independent Auditor's Report } \\
\hline & Unmo & dified & & Modified & \\
\hline & $\begin{array}{c}\text { without } \\
\text { explanatory } \\
\text { paragraph }\end{array}$ & $\begin{array}{c}\text { with an } \\
\text { explanatory } \\
\text { paragraph }\end{array}$ & $\begin{array}{c}\text { with a } \\
\text { warning }\end{array}$ & negative & refusal \\
\hline $\begin{array}{l}\text { 1. Substantial negative influence of the } \\
\text { way of disclosure and disclosure of } \\
\text { information on transactions with } \\
\text { affiliated parties in the financial } \\
\text { statements }\end{array}$ & & & + & + & \\
\hline
\end{tabular}


2. The insufficiency of information about existing transactions with affiliated parties that are significant

Source: compiled by the author on the basis of [13]

Consequently, as it follows from Table 7, under conditions of insufficiently detailed disclosure or nondisclosure of substantive transactions with affiliated parties, the auditor obtains grounds for modifying his / her opinion, as well as refusal to express it.

The final independent auditor's opinion in the final report, which is made public with financial statements and other non-financial information of client companies, must mediate factors that affect not only the reliability of the reporting information, but also the future financial sustainability, adherence to the assumption of the continuity of these companies, namely:

1) The existence of material distortions at the level of statements of the individual and / or consolidated financial statements;

2) The existence and impact of events of significant uncertainty, which depend on the degree of manageability of business risks of companies;

3) The availability and acceptability of the level of unopened (residual) risk.

Consequently, the results of the study showed that the choice of the auditor a type of independent thought at the final stage of the implementation of tasks for audit of reporting information of client companies depends not only on the significance of detected and uncorrected distortions in the financial statements, but also on the nature of the properties of the links of the logical chain, which also mediate this choice, among which: the manifestation and influence of events of significant uncertainty; availability and acceptability of unopened (residual) risk; admissibility of the assumption of the continuity of the company's activities.

\section{CONCLUSIONS}

The results of the study showed that, in order to ensure the proper quality of the audit tasks of the financial statements, the subjects of audit activity are obliged, with due diligence and professional skepticism, to approach the substantiation of their opinion, especially in the event of its modification. The proposed logical chain of formation of professional judgment and independent opinion of the auditor emphasizes the general and specific factors influencing the choice of the type opinion. As a result of the use of such a chain, as well as understanding of the composition of general and specific factors of influence, the basis for the auditor's choice of a particular type of independent thought and its statement in the final official report is created.

The basis of the methodology for determining the influence of factors of modification of the final opinion of the auditor in the official report is the matrix of scenarios of manifestation of the consequences of uncovered risks, which are manifested in events of significant uncertainty. The pragmatic value of this instrument is the ability to map the nature of the effects of uncovered risk events that occur predominantly after the reporting date with the most likely views to make a final decision in accordance with the information received on the management exposure of these risks. The application of the proposed methodology ensures a balanced selection choice of the type of independent auditor's opinion in the final report.

The practical significance of the results of the research is confirmed by the proposed algorithm for determining the influence in observing the assumption of the continuity of activity by the enterprises-clients on the choice of the opinion of the auditor, taking into account the types of its modification.

In general, the proposed developments are tools for effective navigation to fulfill the requirements of International Standards on Auditing by practicing auditors.

\section{REFERENCE LIST}

Adams R. (1995). Osnovyi audita [Fundamentals of Audit]. Moscow : Audit, YuNITI. 398 pages.

Arabyan K.K. (2016).Teoriya audita i organizatsiya auditorskoy proverki [Audit theory and organization of audit]. Moscow: Yuniti-Dana. 324 pages. 
Audit: theory and practice: a textbook for students studying in specialty 08019 "Accounting, analysis and audit" (2010). Edited by Karagod V.S. Moscow: RUDN. 694 pages.

Audit Montgomery (1997). [Montgomery Audit]. Moscow: Audit, YuNITI. 542 pages.

Baranov P.P. (2013). Development of the concept of professional judgment in the audit: theory and methodology - author's abstract. Ph.D. to the soisk. step. Dan. / specialty 08.00.12 - Accounting, statistics. Novosibirsk. Retrieved from https://nsuem.ru/dt/science/infoPoZashitam/BaranovAvtoref.pdf.

Byichkova S.M., Ityigilova E.Yu. (2007). Mezhdunarodnyie standartyi audita [International Standards on Auditing]. Moscow: TK Velbi, Izd-vo Prospekt. 432 pages.

Byichkova S.M. (2011). Audit [Audit: study guide]. Moscow: Magistr, 463 pages.

Dmytrenko I.N., Belousova I.N. (2007). Evolyutsiya kontseptualnogo podhoda k dopuscheniyu nepreryivnosti deyatelnosti sub'ektov hozyaystvovaniya [Evolution of the conceptual approach to the assumption of continuity of business entities]. Mezhdunarodnyiy buhgalterskiy uchet [International accounting]. Vol. 10. pp. 34-38. Vol.11. pp. 9-54.

Dmytrenko I.N., Belousova I.N. (2010). Audit: diagnostika neperyivnosti deyatelnosti predpriyatiy: monografiya [Audit: diagnostics of enterprise failure in activities: monograph]. Donetsk: DonNUET. 320 pages.

Dmytrenko I.M. (2013). Kontseptslya rozvitku auditu korporativnih sistem : monograflya [Concept of development of audit of corporate systems: monograph]. Kyiv: Kondor-Vidavnitstvo. 364 pages.

Dodzh R. (1992). Kratkoe rukovodstvo po standartam i normam audita [Quick Guide to Standards and Audit Standards]. Moscow: Finansyi i statistika, YuNITI. 240 pages.

Generalized information on the state of audit activity in Ukraine for 2014-2017. Retrieved from http:// www.apu.com.ua [in Ukrainian].

International Standards for Quality Control, Audit, Review, Other Provision of Confidence and Related Services of the Council on International Standards on Auditing and Providing Confidence of the International Federation of Accountants (2016-2017). Retrieved from http://www.ifac.org

International Financial Reporting Standard [IFRS]. Retrieved from http://www.ey.com/ifrs

Karagod V.S., L.B. Trofimova (2008). Mezhdunarodnyie standartyi finansovoy otchetnosti: ucheb. posobie [International Financial Reporting Standards: Training Manual]. Moscow: Finansyi i statistika. 265 pages.

Karagod V.S., Golubeva N.A., Erokhina E.I. (2018). The Transparency of Quality Auditor Services. Abstracts \& Proceedings of INTCESS 2018- 5th International Conference on Education and Social Sciences. Istanbul, Turkey. pp.1106-1113.

Karmaykl D.R., Benis M. (1995). Standartyi i normyi audita [Standards and Audit Standards]. Moscow: Audit, YuNITI. 527 pages.

Metodika auditorskoy proverki: protseduryi, sovetyi, rekomendatsii: monografiya / Pod red. N.G. Baryishnikova (2015) [Methods of audit: procedures, tips, recommendations: monograph]. Moscow: INFRA-M. 231 pages.

Mezhdunarodnyie standartyi audita. Uchebnik i praktikum dlya akademicheskogo bakalavriata / Pod. red. T.M. Rogulenko (2017) [International auditing standards. Textbook and workshop for academic undergraduate]. Moscow : Izdatelstvo Yurayt. 341 pages.

Podolskiy V.I., Savin A.A. (2016). Audit : uchebnik [Audit: tutorial]. Moscow: Yuniti-Dana. 687 pages.

Sheremet A.D., Suyts V.P. (2017). Audit: uchebnik [Audit: tutorial]. Moscow: EBS. 375 pages. 
The Law of Ukraine "On Audit of Financial Reporting and Audit Activity" № 2258-VIII of 21.12.2017. Retrieved from http:// www.zakon.rada.gov.ua/go/2258-19 [in Ukrainian].

Voronina L.I. (2018). Audit: teoriya : uchebnik. [Audit: Theory: Tutorial]. V 2 chastyah. Chast 1 [Vol. 1]. Moscow: EBS. 314 pages. 